\title{
Diary of Events
}

\section{4-7 October 2000}

30 Congresso della Società Italiana di Cardiologia Pediatrica, Torino. Enquiries: Segreteria Organizzativa - C.S.C., Viale Mazzini 70, 50132 Firenze, Italy. Tel: 055248 0202; Fax: 055248 0246; E-mail: css@css-congressi.it

\section{5-7 October 2000}

European School for Cardiovascular Pathology Annual meeting: Academic Medical Center, Amsterdam, The Netherlands

This is a three-day program with emphasis on educational aspects.

The theme of day 1 of the educational program will be "Cardiomyopathies and heart failure 2000" and that of day 3 "Heart and lung transplantation pathology". Day 2 will be devoted to oral and poster presentations, as well as educational sessions such as "what is it?" and "the odd case". CME applied for. Registration: no registration fee for the scientific program. For further information and abstract form, please write to:

Marsha Schenker (secretariat)

Department of Cardiovascular Pathology

Academic Medical Center

Meibergdreef 9

1105 AZ Amsterdam, The Netherlands

Tel: +3120 5665646; Fax: +31206914738

e-mail:m.i.schenker@amc.uva.nl

\section{2-15 November 2000}

$73^{\text {rd }}$ Scientific Session of American Heart Association, New Orleans, LA, USA.

Enquiries: AHA, Scientific Meetings, 7272 Greenville Ave, Dallas, TX 75231-4596, USA.

Fax: (+214) 373 3406;

E-mail: scientificconferences@heart.org;

www.americanheart.org/scientific/confer/index.html

\section{2-4 February 2001}

First World Congress on the Fetal Origins of Adult Disease, Mumbai (Bombay), India. Enquiries: Ms Alifiya S Motiwala, MSc, Tel: 009122 6516439/ 6456763; Fax: 0091226516438

E-mail:mrcssc@vsnl.com

www.sneha-india.org

\section{6-9 February 2001}

Harvard Winter Symposium on Congenital Heart Management, Dubai, UAE. Course organizer: Richard A. Jonas. Enquiries: Kathy Milligan, Department of Cardiac Surgery, Children's Hospital, 300 Longwood Avenue, Boston MA 02115, USA. Fax: +(001)6173556742.

E-mail:milligan@a1.tch.harvard.edu

27-31 May 2001

$3^{\text {rd }}$ World Congress of Paediatric Cardiology \& Cardiovascular Surgery, Toronto, Canada. Enquiries: PCCS 2001, c/o Congress Canada, 49 Bathurst Street, Ste.100, Toronto, ON, M5V 2P2, Canada. Tel: +1-416-504-4500; Fax: +1-416-504-4505; E-mail: congca@congresscan.com 